\title{
INVAZIVNE BILJKE KALNIČKIH ŠUMA
}

\section{INVASIVE PLANTS OF KALNIK FORESTS}

\author{
Gabrijel HORVAT ${ }^{1}$ i Jozo FRANJIĆ2
}

\begin{abstract}
Sažetak
U radu se navode invazivne biljne vrste koje se javljaju u šumama Kalnika. Također se navodi i stanje njihove rasprostranjenosti u Hrvatskoj i njihov utjecaj na šume Kalnika. Ukupno je zabilježeno 14 invazivnih vrsta koje u šumama Kalnika stvaraju probleme, a to su - Acer negundo L. (negundovac), Ailanthus altissima (Mill.) Swingle (pajasen), Ambrosia artemisiifolia L. (ambrozija), Amorpha fruticosa L. (čivitnjača), Asclepias syriaca L. (cigansko perje), Conyza canadensis (L.) Cronquist (kanadska hudoljetnica), Echinocystis lobata (Michx.) Torr. et Gray (divlji krastavac), Erigeron annuus (L.) Pers. (krasolika), Impatiens glandulifera Royle (žljezdasti nedirak), Juncus tenuis Willd. (nježni sit), Phytolacca americana L. (vinobojka), Reynoutria japonica Houtt. (japanski dvornik), Robinia pseudoacacia L. (bagrem), Solidago gigantea Aiton (velika zlatnica). Najviše problema u šumama Kalnika čini bagrem, i to na svim tipovima staništa i u sastojinama svih starosnih skupina, a posebno su štete značajne u mladim sastojinama te u sastojinama u fazi obnove. Na površinama nakon čistih sječa a prije pošumljavanja, $u$ mladim sastojinama i osunčanim čistinama starih sastojina u fazi obnove, štetu čine i gusti sklopovi krasolike, ambrozije, žljezdastoga nedirka i vinobojke. Ostale navedene vrste za sada nalazimo uz rubove šuma, cesta, vlaka, obalama vodotoka te na šumskim čistinama, gdje dolaze u manjim skupinama ili pojedinačno te za sada ne čine ozbiljne štete, ali su stalna prijetnja autohtonim vrstama, kao i bioraznovrsnosti.
\end{abstract}

KLJUČNE RIJEČI: šume Kalnika, autohtone vrste, invazivne vrste, bioraznovrsnost.

\section{UVOD}

\section{INTRODUCTION}

Kalnik je gorje smješteno u sjeverozapadnom dijelu Hrvatske. Proteže se između Zagorja, Prigorja i Podravine, pripada žumberačko-medvedničko-kalničkom gorskom nizu, pružajući se u smjeru jugozapad-sjeveroistok. Na zapadu dopire do Ivanščice i proteže se na istok do Bilogore. Najviši vrh je Vranilec (643 m n. v.). Po svom postanku spada među naša najmlađa gorja. Građen je uglavnom iz karbonatnih stijena, posebice $u$ južnom i zapadnom dijelu, a prema istoku prelazi u silikate. Na takvim podlogama nastale su skupine bazičnih tala na vapnenasto-dolomitnoj podlozi te kisela tla na podlogama pijeska, pješčenjaka i šljunka. Reljef Kalnika je vrlo razveden, neravan, strm, ispresijecan brojnim jarcima i hrptovima, pri čemu je južna strana blaže valovita i pitomija, te stoga naseljenija, ali i manje šumovita. Sjeverna strana, posebno od zapada, izrazito je razvedena i strma, a prema istoku postupno prelazi u blaže padine. Šume u sjevernom dijelu dosežu sve do doline Bednje. Kalničko područje je vrlo bogato izvorima vode koje teku brojnim vodotocima i to sa sjevera i sjeveroistoka prema Dravi, a ostali prema Savi. Kalnik se nalazi u području umjereno-kontinentalne klime, sa srednjom godišnjom temperaturom od $9,8^{\circ} \mathrm{C}$ i prosječnom količinom oborina od približno $900 \mathrm{~mm}$.

\footnotetext{
${ }^{1}$ Dr. sc. Gabrijel Horvat, Hrvatske šume d.o.o. Zagreb, UŠP Koprivnica, Šumarija Ludbreg, Koprivnička 2, HR-42230 Ludbreg, gabrijel.horvat@hrsume.hr

${ }^{2}$ Prof. dr. sc. Jozo Franjić, Sveučilište u Zagrebu-Šumarski fakultet, Svetošimunska 25, HR-10000 Zagreb, franjic@sumfak.hr
} 
Autohtona šumska vegetacija Kalnika definirana je njegovim stanišnim uvjetima, ali i trajnim i snažnim utjecajem čovjeka zbog relativno guste naseljenosti i povoljnih uvjeta za život ljudi. Najzastupljenije su biljne zajednice obične bukve koje pokrivaju najveće površine i tvore najljepše i najvrjednije sastojine. Osim toga, prirodno se javljaju i zajednice hrastova - lužnjaka, kitnjaka i medunca. Na Kalniku se još javljaju i šumske zajednice običnoga graba i crne johe. Velike površine zauzimaju kulture četinjača, koje su umjetno podignute sredinom 20. stoljeća.

Šumska vegetacija Kalnika osim domaćih (autohtonih) vrsta sadrži sve više stranih (alohtonih) vrsta. Alohtonu floru čine vrste čije je pojavljivanje uzrokovano ljudskim aktivnostima (unešene, strane, pridošle vrste), a unešene su namjernim ili nenamjernim djelovanjem. Neke od tih vrsta su se prilagodile novim stanišnim uvjetima i prošle su proces udomaćivanja, u smislu intenzivnoga razmnožavanja, brzoga rasta i razvoja (često bržega i snažnijega od domaćih vrsta) i u nedostatku prirodnih neprijatelja pričinjavaju ekološke i ekonomske štete ili štete po zdravlje ljudi. Takve su vrste ponajprije prijetnja biološkoj raznovrsnosti, jer vrlo brzo zaraštaju prirodna staništa, a nazivaju se invazivne vrste. Neofiti su pak alohtone vrste novijega doba (nakon otkrića Amerike) za razliku od arheofita koji su starijega datuma (do otkrića Amerike). Ova vrsta vegetacije nastanjuje šumske i poljoprivredne površine, ponajprije vlažna i svjetla staništa (rubovi šuma, čistine nakon sječe, prirodne enklave), u početku najčešće u dolinama uz vodotoke i komunikacije (Mitići dr. 2008). Posebno uspijevaju na ruderalnim i drugim antropogenim staništima. Vrlo su prilagodljive i u kratkom vremenu se udomaće, a neke formiraju i nove biljne zajednice s autohtonom florom. Podrijetlom su uglavnom iz sličnih stanišnih prilika Azije i Amerike.

Procjenjuje se da udio alohtone flore u nacionalnim florama doseže $30-50 \%$ u ukupnom broju vrsta. Dakako da utjecaj svih alohtonih vrsta nije jednak, jer neke vrste su korisne (uzgoj u kulturama), nečiji utjecaj je neutralan, a najviše je onih štetnoga utjecaja. Strane invazivne vrste su na globalnoj razini druga najveća prijetnja bioraznovrsnosti, odmah nakon procesa uništavanja prirodnih staništa.

U Europi se navodi više od 11.000 biljnih i životinjskih alohtonih vrsta, od kojih se do $15 \%$ smatra invazivnima, a šteta koju prouzrokuju procjenjuje se na 12 milijardi eura. U Hrvatskoj je alohtona vegetacija također vrlo rasprostranjena (Pandža i dr. 2001; Nikolić i dr. 2014) i do sada je zabilježeno preko 600 invazivnih biljnih vrsta, dio kojih se javlja i u šumama.

Slična učestala pojavnost nekih invazivnih vrsta uočava se zadnjih godina i u kalničkim šumama, gdje se u nekoliko godina događa intenzivan proces sušenja kultura četinjača (obična smreka, europski ariš, američki borovac, crni bor). Proces je vrlo progresivan i zahvaća sve kulture četinjača, što predstavlja ozbiljan problem u sanaciji tih površina zbog velike količine drvne mase loše kvalitete i uporabne vrijednosti koju treba u kratkom roku posjeći i pripremiti površinu za obnovu. Intenzivnim sušenjem i sječom velike površine su ogoljene. Radovi sječe i pripreme staništa obavljaju se mehanizirano, što uz preveliku uporebu teške mehanizacije prekomjerno oštećuje tlo, mijenjajući mu strukturu, sastav površinskih slojeva i dr. Takve su površine, zbog ograničenoga dotoka svijetla na tlo u kulturama bile gotovo sterilne i najčešće bez drugih biljaka. Naglim otvaranjem i dolaskom velike količine svjetla na tlo, nastali su pogodni uvjeti za nadolazak vrsta prilagođenih na puno svjetla, pa tako i alohtonih. Prenositelji su osim prirodnih bili i antropogeni pomoću strojeva (traktori, kamioni, automobili i dr.). Velike količine organske materije koja se nagomilala na tlu (izbojci, iglice, kora i dr.), iznadprosječne temperature te velike količine oborina stvorili su uvjete za brzu razgradnju biomase i intenzivan rast i razvoj nove vegetacije, u čemu su se vrlo dobro snašle invazivne vrste zbog svojih komparativnih prednosti. Tako su nastale čitave sastojine novih biljnih vrsta koje su u potpunosti prekrile tlo, a i obilno su plodonosile, te se očekuje njihova velika brojnost u idućem razdoblju. Najbrojnije zajednice invazivnih vrsta na području Kalnika pojavljuju se u sjeveroistočnom dijelu, gdje prevladavaju silikatne podloge na kojima dolaze kiselija tla koja su povoljna za ove vrste, jer zbog svojega podrijetla (Sjeverna Amerika i Azija) preferiraju takva tla. Prema vrsti staništa najveći broj jedinki i zajednica invazivnoga bilja javlja se na površinama čistih sječa nakon sušenja kultura četinjača, u kojima osim puno svjetla i čistih površina postoje u tlu velike količine nerazgrađenoga humusa, zbog čega je podloga kisela (usp. Perković i dr. 2007; Horvat 2011, 2012), a time i povoljna za razvoj ovoga tipa vegetacije. To će svakako predstavljati osim ekološkoga i velik ekonomski problem vezan uz troškove njihovoga uklanjanju, kako bi se omogućilo nesmetano izvođenje radova pošumljavanja i njege mladih sastojina te privođenje površina autohtonoj vegetaciji.

\section{MATERIJAL I METODE MATERIAL AND METHODS}

Terenska istraživanja provedena su od svibnja do kolovoza tijekom 2003., 2009. i 2010. godine s ciljem istraživanja šumske vegetacije i sukcesije vegetacije saniranih površina nakon sušenja kultura četinjača na Kalniku. Dodatna ciljana istraživanja provedena su tijekom druge polovice 2014. godine na cijelom području šumskih površinama Kalnika, s posebnim naglaskom na mlade sastojine i sastojine u fazi pomlađivanja, tj. površine s puno svjetla i potencijalna staništa invazivnih vrsta. U radu su korišteni rezultati prethodnih istraživanja, a za određivanja taksona biljnih vrsta korišteni su taksonomski ključevi Javorka i Csapody (1991), 
Martinčić i dr. (1999), Domac (1994), Rotmahler (2000), Franjić i Škvorc $(2010,2014)$. Potencijalna opasnost i moguća štetnost rađena je procjenom. Za utvrđivanje prisutnosti invazivnih biljaka korišsteni su podaci o rasprostranjenosti tih vrsta na području Hrvatske iz relevantne on-line baze podataka http.//hirc.botanic.hr/fcd/Invazivne Vrste (Nikolić 2015).

\section{DANAŠNJE STANJE RASPROSTRANJENOSTI INVAZIVNIH BILJAKA U ŠUMAMA KALNIKA PRESENT STATE OF DISTRIBUTION OF INVASIVE PLANTS IN FORESTS OF KALNIK}

\section{Acer negundo L. (Aceraceae) - negundovac}

(= Negundo aceroides Moench, N. fraxinifolium/Nutt./ DC.) (= pajavac, jasenolisni javor, javor perasti, američki javor, bijeli javor)

eng. Box-elder, Ashleavedmaple; njem. Eschenahorn; fra. Erable negundo; tal. Aceroamericano

Listopadno drvo podrijetlom iz Sjeverne Amerike. U Europu (Velika Britanija) unesen je namjerno 1688. godine kao dekorativna vrsta. Do sada je naturaliziran ili se kultivira još u Južnoj i Srednjoj Americi, Aziji, Australiji i Novom Zelandu. Na području Hrvatske je evidentiran početkom 20. stoljeća, gdje se uzgaja u parkovima i drvoredima. Najviše dolazi u sjeverozapadnom i istočnom dijelu Hrvatske te Dalmaciji. Termofilna je vrsta polusjene, široke ekološke amplitude. Preferira tla s izmjeničnom vlagom, propusna, s osrednjom količinom humusa i dušika te umjerene kiselosti. Zbog velike prilagodljivosti podnosi i vrlo siromašna tla, mjesta izložena suncu, sušu, hladnoću, pa i zasjenu. Dolazi u kontinentalnim do submediteranskim uvjetima, na prirodnim suhim i močvarnim staništima šuma i livada, ali i na antropogeno utjecanim položajima. Visoko je kompetitivna vrsta koja istiskuje prirodnu vegetaciju, po-

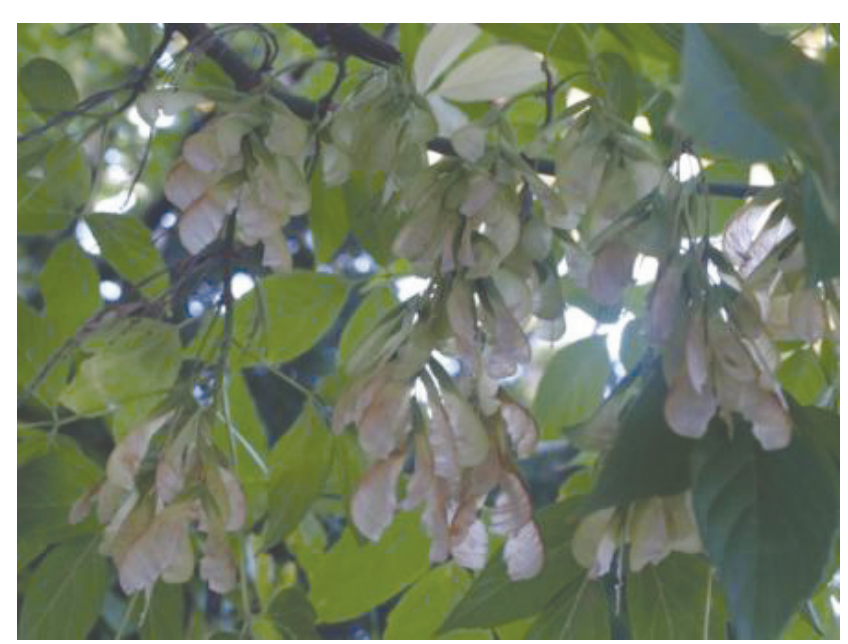

Slika 1. Negundovac (Acer negundo L.). sebice u mladosti kada raste više od jednoga metra godišnje. Ne dostiže duboku starost, doživi do pedeset godina i u pravilu nestaje. Bogato plodonosi petnaestak godina, razmnožava se sjemenom, ali i vrlo učinkovito vegetativno izbojcima iz korijena. Cvjeta u ožujku i travnju prije listanja, a pelud izaziva alergije (Franjić i Škvorc 2010; Šoštarić 2011; Nikolić 2014).

$\mathrm{Na}$ Kalniku dolazi u nižim dijelovima, na zapuštenim površinama, uz rubove šume, sječine, prosjeke i putove. Zabilježen je krajem prošloga stoljeća. Dostiže dimenzije jačega grma. Zbog pojedinačnoga javljanja ili u manjim skupinama, za sada ne pričinjava ozbiljnije štete na autohtonoj vegetaciji niti u šumi, a ni ne očekuje se veća invazija. Uklanja se mehanički.

\section{Ailanthus altissima (Mill.) Swingle (Simaroubaceae) - pajasen}

(= A. cacodendron /Ehrh./ Schinz et Thell., A. giraldii Dode, A. glandulosa Desf., A. peregrina /Buc'hoz/ Barkley, A. sutchuensis Dode, A. vilmoriniana Dode, Pongelion cacodendron /Ehrh./ Farw., P. glandulosum /Desf./ Pierre, Rhus cacodendron Ehrh., Toxicodendron altissimum Mill.) (= žljezdasti pajasen, bogač, rajsko stablo, jelš, pajesan žljezdasti, kiselo drvo)

eng. Tree of Heaven, Ailanthas, China Sumac; njem. Chinesischer Götterbaum; fra. Ailante glandulex

Listopadno drvo podrijetlom iz Kine. U Europu je unesen 1751. godine kao ukrasna biljka. Danas dolazi u Europi, Sjevernoj i Južnoj Americi, Aziji, Africi i Australiji. U Hrvatskoj je prvi put zabilježen 1914. godine (vjerojatno je postojao i ranije), prvo se koristio za pošumljavanje i stabilizaciju pjeskovitih staništa (Đurđevački pijesci) i kao ukrasna vrsta u drvoredima. Danas predstavlja poseban problem u primorskim krajevima. Pajasen je vrsta široke ekološke amplitude i velike otpornosti. Preferira toplija i sunčanija staništa (mediteranskoga i submediteranskoga tipa), ali i vrlo dobro podnosi temperaturne razlike, kao i količine dostupne vlage. Dolazi na različitim tipovima tala, dobro podnosi uvjete siromašnih tala, kao i zagađenost zraka. Naseljava svjetla mjesta uz prometnice, putove, rubove šuma te sva antropogena staništa. Pajasen se vrlo uspješno razmnožava sjemenom (obilno plodonosi), ali i vegetativno iz panjeva, tjeranjem podzemnih podanaka te fragmentima korijena. Svojim agresivnim širenjem nadrasta konkurentske autohtone vrste, a uz to i luči aleopatske tvari (ailanthon) kojima onemogućava razvoj drugih vrsta. Biljni sok je iritabilan za ljudsku kožu, ali i štetan po zdravlje u slučaju dužega kontakta (Franjić i Škvorc 2010; Boršić 2011; Nikolić 2014).

Pajasen je na Kalniku uočen 80-tih godina prošloga stoljeća, a javlja se uz rubove šuma i puteve. Češći i agresivniji je u nizinskim dijelovima podno Kalnika ,odakle postupno na- 


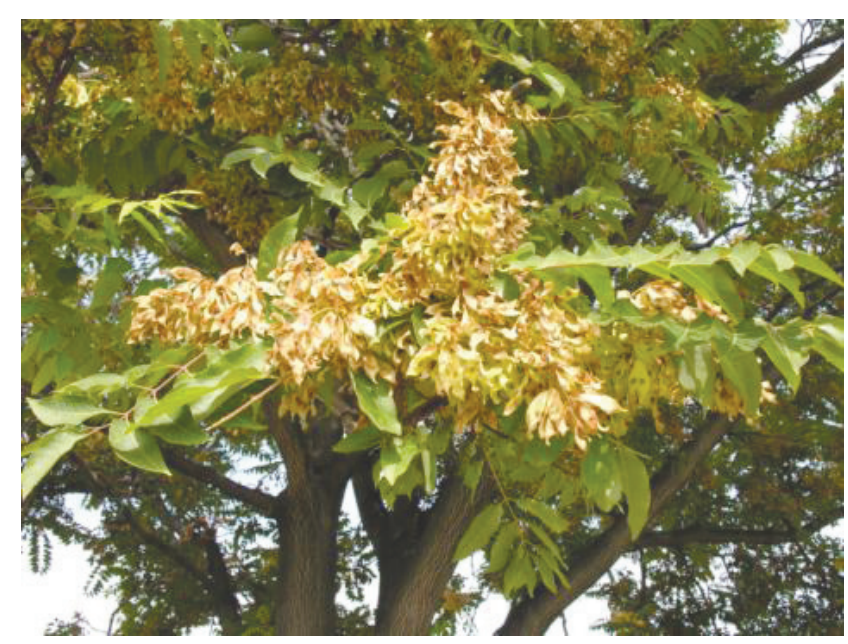

Slika 2. Pajasen (Ailanthus altissima /Mill./ Swingle).

dire. Za sada ne pričinjava ozbiljnije štete u šumama niti u okolišu Kalnika, ali je primjetno sve jače širenje i potencijalna je opasnost. Najčešće se uništava mehanički.

\section{Ambrosia artemisiifolia L. (Asteraceae) - ambrozija}

(= A. elatior $\mathrm{L}$.)

(= pelinolisni limundžik, obični limundžik, partizanka)

eng. Short Ragweed, American Wormwood, Roman Ragweed; njem. Ambrosie (Hohe); fra. Ambroisie

Jednogodišnja zeljasta bilika, podrijetlom iz Sjeverne Amerike. Nenamjerno je unesena s drugim sjemenjem u Europu krajem 19. stoljeća. Do sada je zabilježena u Aziji, Australiji i Južnoj Americi. U Hrvatskoj je prvi put zabilježena u okolici Pitomače 1941. godine (Josip Kovačević), otuda i jedan od narodnih naziva" partizanka“. Danas ju nalazimo na području cijele Hrvatske, a posebno obilno na sjeveru i u Slavoniji. Muški cvjetovi stvaraju ogromne količine peluda (cvjeta od lipnja do listopada) koje raznosi vjetar na udaljenost i do $300 \mathrm{~km}$, a klijavost zadržava i do 40 godina. Jedan je od najrasprostranjenijih korova. Ambrozija nastanjuje sva svjetla, napuštena i antropogena staništa. Vrlo je široke ekološke amplitude, posebno je tolerantna na vlagu i temperaturu, te je stoga vrlo agresivna i široko rasprostranjena. Otporna je i na mehaničko uklanjanje, jer i nakon košnje ponovo potjera. Najveći utjecaj ima na ljudsko zdravlje jer izaziva jake alergije u ljudi, ali svojom agresivnošću potiskuje i autohtonu vegetaciju (Peternel i dr. 2005; Boršić 2011; Horvat 2011; Nikolić i dr. 2014).

$\mathrm{Na}$ Kalniku se također javlja na svim za nju povoljnim staništima (čistine, rubovi šume, putovi, zapuštena poljoprivredna zemljišta i ruderalna staništa), svih nadmorskih visina i ekspozicija. Posebno dobre uvjete nalazi na čistim sječinama, posebno na površinama nakon sječe osušenih kultura četinjača. Štete na Kalniku čini zauzimanjem staništa gustim sklopom koji onemogućava jesenska pošumlja-

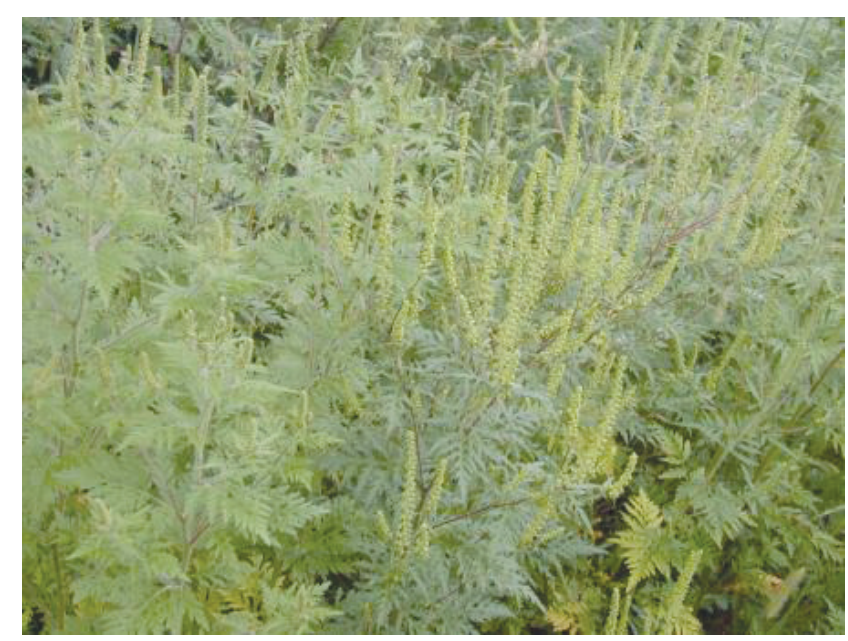

Slika 3. Ambrozija (Ambrosia artemisiifolia L.).

vanja ili zasjenjuje stabljike mladi sastojina tijekom vegetacije. Uklanja se mehanički i kemijski. Kemijski glifosatima na čistim površinama prije pošumljavanja (u Americi je dokazana rezistentnost na glifosate), a mehanički žetvom u mladim sastojinama. Metode nisu posebno učinkovite u smislu potpunoga uništenja, ali nije štetna za odrasle sastojine.

\section{Amorpha fruticosa L. (Fabaceae) - čivitnjača}

(= A. angustifolia F. E. Boynton, A. arizonica Rydb., A. bushii Rydb., A. croceolanata Watson, A. curtissii Rydb., A. dewinkeleri Small, A. emarginata Eastw., A. emarginata Sweet, A. fragrans Sweet, A. fruticosa f. crispa /G. Kirchn./ C. K. Schneid., A. fruticosa var. angustifolia Pursh, A. fruticosa var. caroliniana/Croom/S. Watson, A. fruticosa var. coerulea Loudon, A. fruticosa var. crispa G. Kirchn., A. fruticosa var. croceolanata/Watson/ Mouill., A. fruticosa var. emarginata Pursh, A. fruticosa var. humilis/Tausch/ C. K. Schneid., A. fruticosa var. lewisii Loudon, A. fruticosa var. oblongifolia E. J. Palmer, A. fruticosa var. occidentalis / Abrams/ Kearney et Peebles, A. fruticosa var. pendula (Carriere) Dippel, A. fruticosa var. tennesseensis /Kunze/ E. J. Palmer, A. fruticosa var. typica /L./ C. K. Schneid., A. fruticosa var. vulgaris Pursh, A. humilis Tausch, A. occidentalis Abrams, A. occidentalis var. arizonica /Rydb./ E. J. Palmer, A. occidentalis var. emarginata E. J. Palmer, A. pendula Carriere, A. tennesseensis Kunze, A. virgata Small)

(= amorfa, bagremac, kineski bagrem)

eng. Bastard Indigo; njem. Gewönlicher Bastardindigo, Schein Indigo; fra. Faux indigo

Listopadni grm namjerno unesen iz Sjeverne Amerike 1724. godine kao dekorativna vrsta, odnosno vrsta za smirivanje klizišta, izradu živica i pletenih predmeta, te kao vrijedna medonosna biljka. Osim u Sjevernoj Americi i Europi danas se javlja još i u Južnoj Americi, Africi i Aziji. U nizinski dio Hrvatske unesena je početkom 20. stoljeća, ponajprije za 


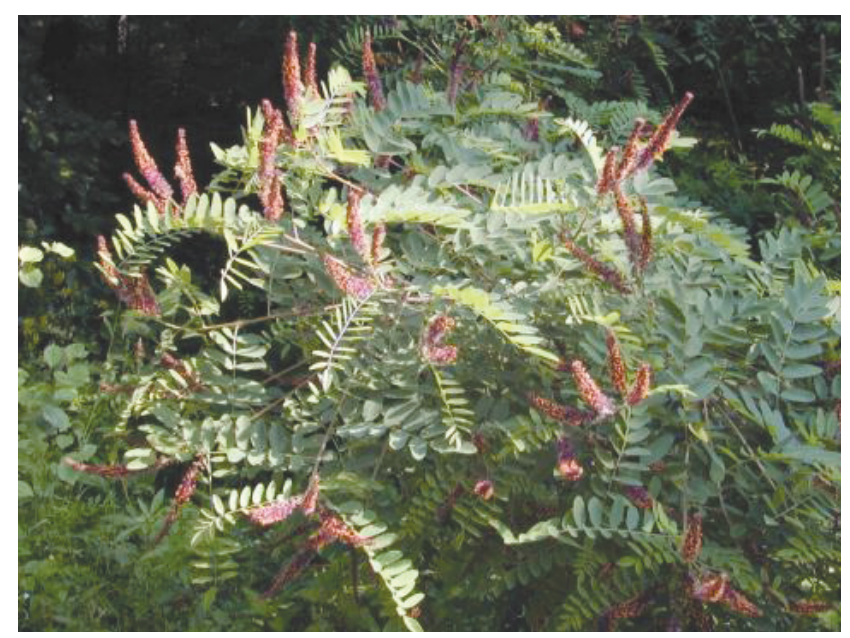

Slika 4. Čivitnjača (Amorpha fruticosa L.).

zaštitu i stabilizaciju kosina i nasipa željezničkih pruga te kao medonosna biljka. Vrsta je široke ekološke amplitude, sklonija termofilnijim staništima. Danas je najviše ima u sjeverozapadnim i istočnim dijelovima Hrvatske, ali i diljem zemlje uglavnom uz vodotoke. Preferira srednje vlažna do vlažna staništa, osrednje bogata humusom i dušikom, umjerene kiselosti. Podnosi također i djelomičnu zasjenu, ali i stajaću vodu. Najčešće dolazi uz vodotoke, na prirodnim ili poluprirodnim staništima. Naraste do dva metra u visinu, posebno u mladosti, kada nadrasta sve autohtone vrste tvoreći gusti neprohodni sklop, čime onemogućava dolazak drugih vrsta. Drastično utječe na biološku raznovrsnost. Posebno velike štete čini u mladim sastojinama hrasta lužnjaka, gdje prerasta autohtone vrste i otežava obnovu šuma (međurječje Save, Dunava i Drave). Cvjeta tijekom lipnja i oprašuje se kukcima, obilna je i vrijedna pčelinja paša, što je čini korisnom biljkom. U simbiozi s nekim bakterijama veže elementarni dušik iz zraka i njime obogaćuje tlo. Osim sjemenom, vrlo dobro se razmnožava i vegetativno tjeranjem izbojaka iz korijena (Franjić i Škvorc 2010; Boršić 2011; Krpan i dr. 2011; Nikolić i dr. 2014).

Na Kalniku se javlja u nižim dijelovima, pojedinačno ili u manjim skupinama uz vodotoke, odakle polako ulazi u rubove šuma. Prve spoznaje o nalazištima na području Kalnika datiraju iz druge polovice prošloga stoljeća. Nisu uočene značajne štete u šumskim sastojinama. Uklanja se mehanički.

\section{Asclepias syriaca L. (Asclepiadaceae) - cigansko perje}

\section{(=A. cornuti Decne)}

(= prava svilenica, pravo cigansko perje, kinder, ciganjsko perje, svioni dubac, svionica, dubac svilni, pustenolistna svilenica, svilenica)

eng. Common Milkweed; njem. Seidenpflanze
Zeljasta trajnica podrijetlom iz Sjeverne Amerike. U Europu donesena namjerno u 17. stoljeću ponajprije kao ukrasna biljka, kasnije se u Njemačkoj koristila za proizvodnju prediva. Još je zabilježena u Sjevernoj Americi, Bliskom istoku i u Japanu. Za Hrvatsku se prvi put navodi u drugoj polovici 19. stoljeća. Danas se najčešće javlja na sjeverozapadu i istoku Hrvatske. Primarno dolazi na toplim i osunčanim staništima. Preferira pjeskovita, prozračna, ne previše bogata tla dušikom i humusom. Pokazatelj je umjereno vlažnih do vlažnih tala umjerene kiselosti. Ponajprije naseljava antropogena staništa uz putove, svijetle pruge, riječne nasipe, smetlišta, ali i otvorene poljoprivredne i šumske površine. Osim sjemenkama, uspješno se razmnožava i vegetativno podancima. Svojom pojavom utječe na autohtonu vegetaciju promjenom prirodnoga sastava zajednica. Sok biljke sadrži srčane glikozide zbod čega je otrovna, a koristi se i u ljekovite svrhe (Šoštarić 2011; Horvat2011; Nikolić i dr. 2014). Na Kalniku se javlja uglavnom na antropogenim staništima i nižim dijelovima. Najčešće je zastupljena na čistim sječinama nakon sušenja kultura četinjača, posebno na mjestima prejakoga korištenja mehanizacije. Uništava se mehanički, košnjom u mladim sastojinama ili kemijski (glifosati) kod pripreme staništa za pošumljavanje. Štete na šumama od ove vrsta za sada nisu značajnije.

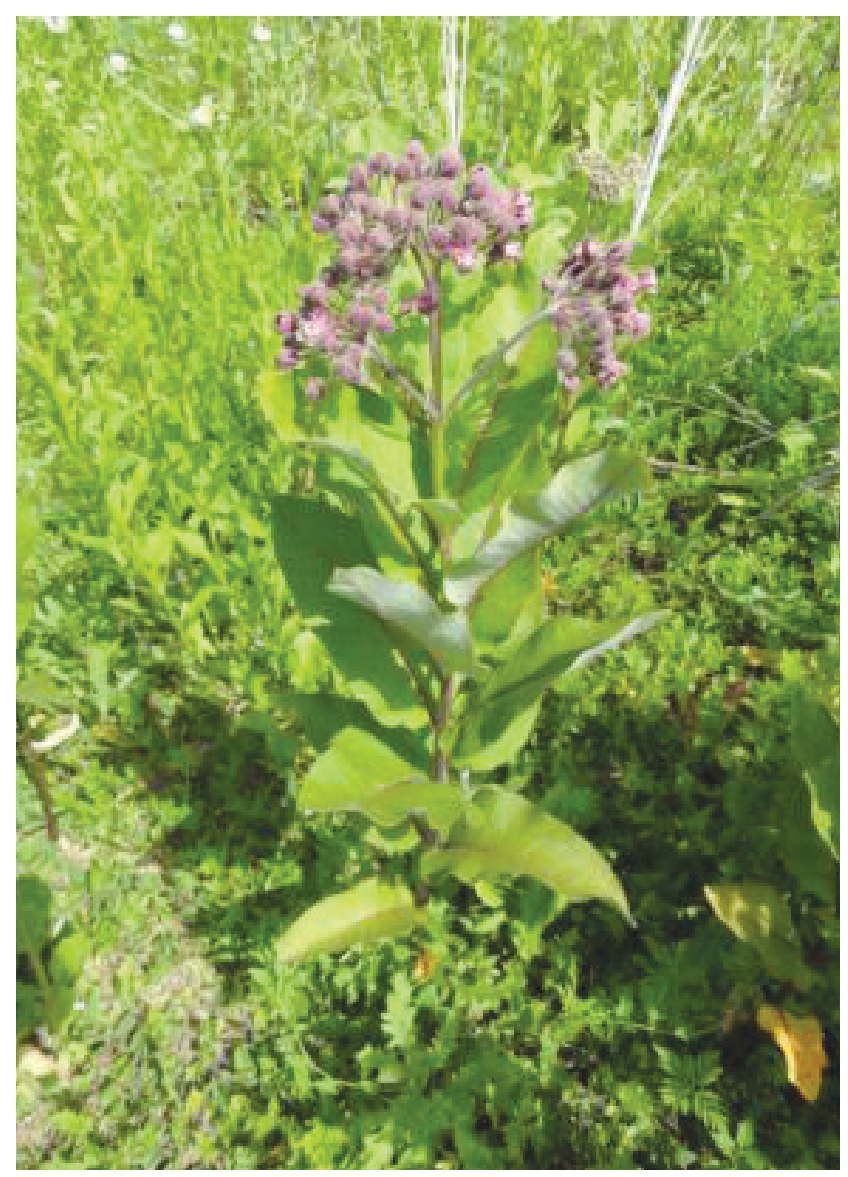

Slika 5. Cigansko perje (Asclepias syriaca L.). 


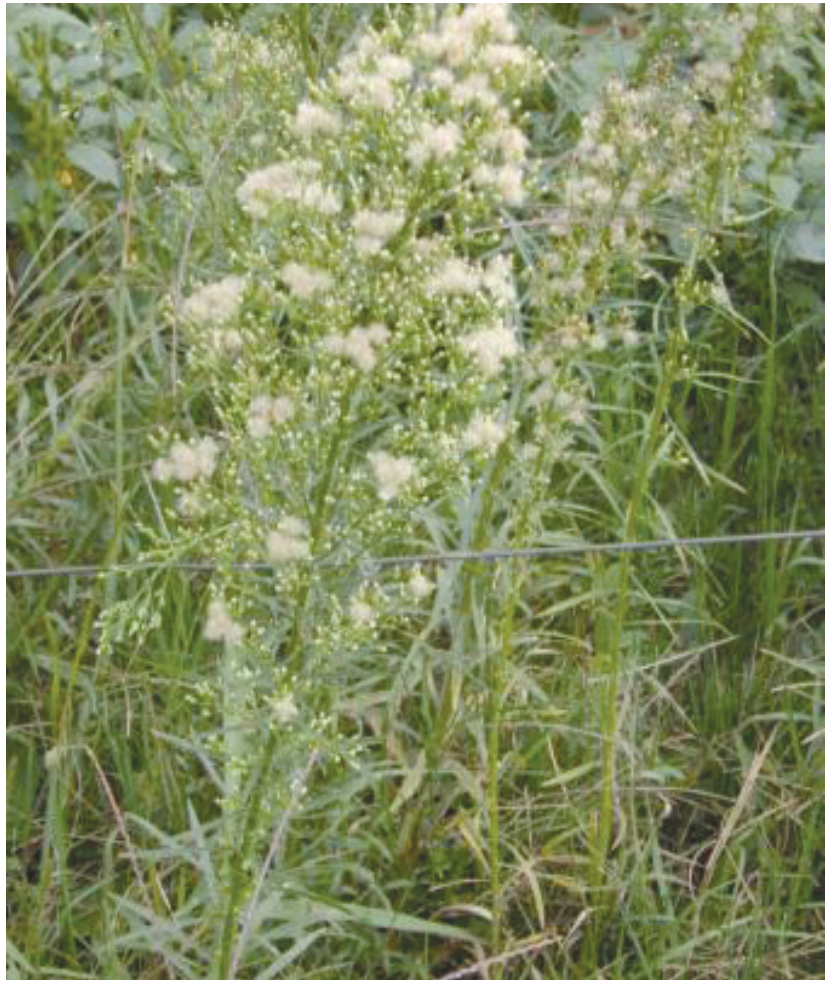

Slika 6. Kanadska hudoljetnica (Conyza canadensis /L./ Cronquist).

\section{Conyza canadensis (L.) Cronquist (Asteraceae) - kanadska hudoljetnica}

\section{(= Erigeron canadensis L.)}

(= hudoljetnica, repušnjača)

eng. Canadian Fleabane; njem. Kanadisches Berufkraut; fra. Erigéron du Canada; tal. Scoamatta

Kanadska je hudoljetnica jednogodišnja zeljasta biljka podrijetlom iz Sjeverne i Južne Amerike. U Europu je unesena nenamjerno 1640. godine. Danas je rasprostranjena po toplijim krajevima cijeloga svijeta. $U$ Hrvatskoj je zabilježena prvi put 1847. godine u Dalmaciji, a danas je rasprostranjena na cijelom području zemlje kao jedna od najinvazivnijih vrsta. Biljka je vrlo široke ekološke amplitude. Nastanjuje sva tla, od bogatih dušikom do siromašnih te dobro podnosi sušu. Biljka je svjetla, ali podnosi i zasjenu. Otporna je na paljenje, sveukupno vrlo kompetitivna, stoga je vrlo štetna kao korov, vrlo je alergena, otrovna i prenositelj štetnih bolesti i kukaca (Vuković 2011; Horvat 2011; Nikolić i dr. 2014).

U šumama Kalnika dolazi na cijeloj površini, uglavnom na osunčanim staništima. Najčešće se javlja kao štetni korov u mladim prirodno pomlađenim sastojinama, a posebice na golim površinama nastalim čistom sječom posušenih kultura četinjača. Kao korovna vrsta zauzima staništa autohtonoj vegetaciji, ali i zasjenjuje pomladak mladih sastojina. Uklanja se kemijski (glifosati) zajedno s ostalim korovima u pripremi staništa za pošumljavanje, odnosno mehanički u njezi mladih sastojina.

\section{Echinocystis lobata (Michx.) Torr. et Gray (Cucurbitaceae) - divlji krastavac}

(= E. echinata Britton, Microampelis lobata Michx., Sicyos lobata Michx.)

(= uljna bućica, bodljasta tikvica, bodljasti krastavac)

eng. Prickly Cucumber, Wild Balsam Apple; njem. Stachelgurke

Jednogodišnja penjačica podrijetlom iz Sjeverne Amerike. Namjerno je unesena u Europu kao ukrasna i ljekovita biljka krajem 19. stoljeća, moguće i transportom vune iz Amerike. U Hrvatskoj je prvi put zabilježena pedesetih godina prošloga stoljeća, a najviše uspijeva u nizinskom sjeverozapadnom i istočnom dijelu Hrvatske (sporadično u Gorskom kotaru i Dalmaciji). Biljka je ponajprije umjereno toplih do toplih staništa. Uspijeva u uvjetima polusjene, na vlažnim, svježim tlima, umjereno bogatih dušikom i humusom, umjerene kiselosti. Najčešće dolazi u dolinama vodotoka te na ruderalnim staništima uz naselja, kao i na poljoprivrednim i šumskim površinama, gdje nalazi oslonac za penjanje. Uspješno se razmnožava sjemenkama, koje se dobro rasprostiru vodom. Štetna ja kao korovna biljka na poljoprivrednim površinama, potencijalni je prenositelj nekih virusnih oboljenja na kultiviranim biljkama. Penjanjem zasjenjuje i guši domaćina. Sadrži otrovan spoj kukurbitacin (Trinajstić i dr. 1991; Kranjčev 2007; Vuković 2011;Franjić i Škvorc 2014; Nikolić i dr. 2014).

$\mathrm{Na}$ Kalniku dolazi također na sličnim staništima, a prve biljke zabilježene su u sjeveroistočnom dijelu uz vodotoke

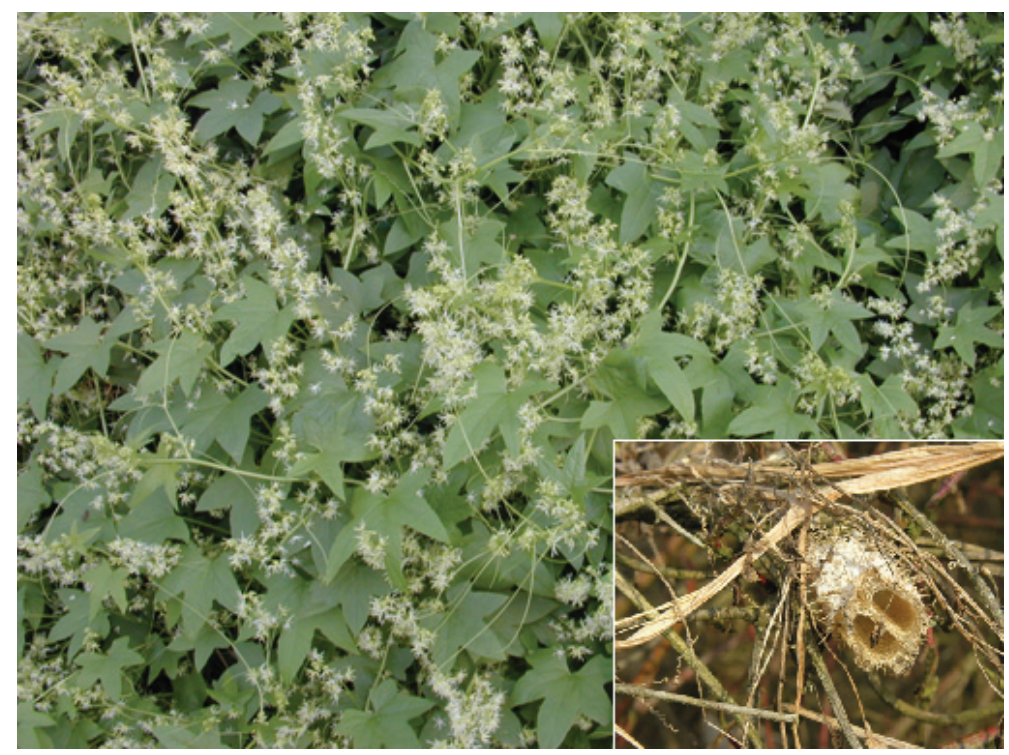

Slika 7. Divlji krastavac (Echinocystis lobata /Michx./ Torr. et Gray). 
gdje je došla iz nizinskih dijelova. Po šumu je štetna kao penjačica koja zasjenjuje dio krošnji stabala po kojima se penje, najčešće po rubnim stablima. Štete nastaju također od vlažnoga snijega koji se nataloži na gustom spletu izbojaka koje zapleće oko domaćina. Uklanja se mehanički.

\section{Erigeron annuus (L.) Pers. (Asteraceae) - krasolika (= Aster annuus L., Phalacroloma annuum/L./ Dumort., Ste- nactis annua /L./ Nees, Stenactis bellidiflora A. Braun,) (= djeteljina krasolika, jednogodišnja krasolika) njem. Einjähriger Feinstrahl}

Zeljasta jednogodišnja ili dvogodišnja biljka podrijetlom iz Sjeverne Amerike. Unesena je namjerno u Europu krajem 17. stoljeća ponajprije kao ukrasna biljka, kasnije se kori-

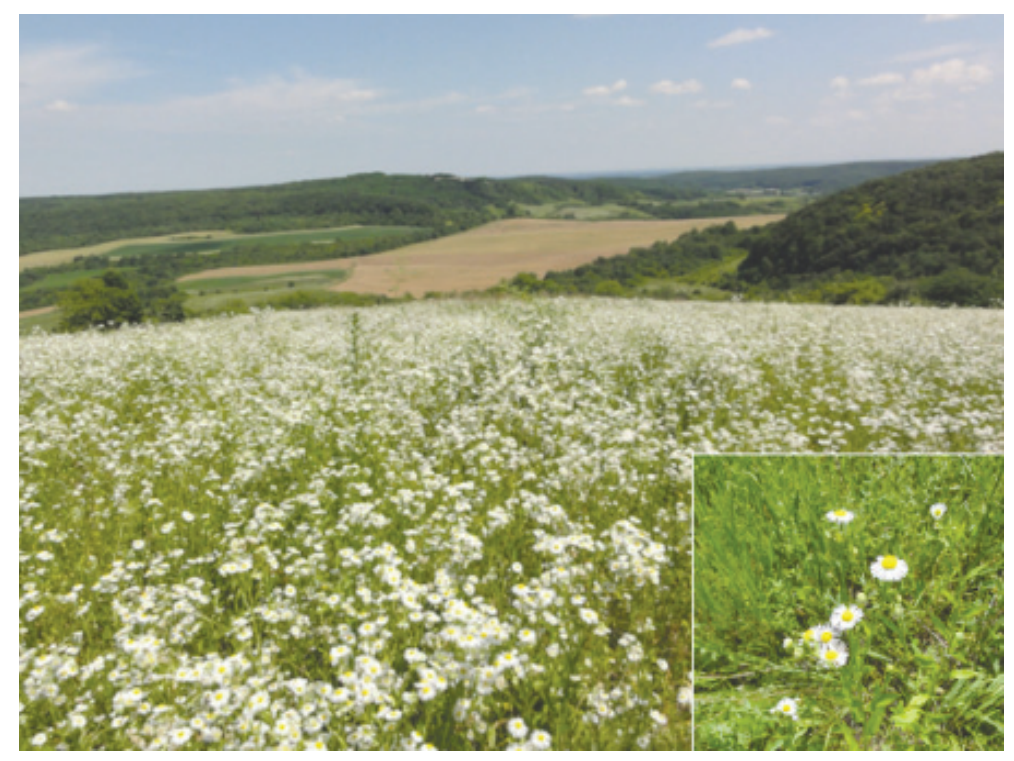

Slika 8. Krasolika (Erigeron annuus /L./ Pers.).



Slika 9. Žljezdasti nedirak (Impaetiens glandulifera Royle). stila u narodnoj medicini. U Hrvatskoj je prvi put zabilježena 1857. godine u okolici Zagreba, Moslavini i Slavoniji, odakle se do danas rasprostranila po cijeloj zemlji. Dolazi na svijetlim do polusjenovitim mjestima. Preferira staništa bogata dušikom i osrednjom količinom humusa umjerene kiselosti. Nalazi se na svim tipovima staništa, od kontinentalnih do submediteranskih. Nastanjuje zapuštene poljoprivredne površine, rubove putova, cesta i drugih svijetlih pruga, oko naselja, ali i na šumskim čistinama. Karakteristična je za sva antropogena staništa. Izuzetno je otporna i agresivna, kompetitivna je autohtonoj vegetaciji koju istiskuje svojom pojavom. Iznimno je otporan korov (Vuković 2011; Horvat 2011; Nikolić i dr. 2014).

$\mathrm{Na}$ Kalniku dolazi uglavnom na antropogenim staništima, uz puteve, rubove šuma, na zapuštenim oranicama. Posebno dobro uspijeva na čistinama nakon sječe kultura četinjača, mjestimično u slabije pomlađenim prirodnim mladim sastojinama. Tvori guste i teško prohodne sastojine koje onemogućavaju pošumljavanje, a djelomično i zasjenjuje već pomlađene površine. Uklanjanje se obavlja kemijski (glifosati) kod pripreme staništa za pošumljavanje ili žetvom u mladim sastojinama.

\section{Impatiens glandulifera Royle (Balsaminaceae) - žljezdasti nedirak}

\section{(= I. roylei Walp.)}

eng. Himalayan Balsam, Policeman's Helmet; njem. Drüsiges Springkraut, Indisches Spring= kraut

Jednogodišnja zeljasta biljka podrijetlom iz Azije, a namjerno je unesena u Veliku Britaniju 1839. godine kao ukrasna biljka. Danas je rasprostranjena na području Europe, Sjeverne Amerike, Azije i Novoga Zelanda. U Hrvatskoj se prvi put spominje sedamdesetih godina prošloga stoljeća. Danas je najviše nalazimo na području sjeverozapadne i istočne Hrvatske, te na području Pokuplja. Cvjeta u srpnju i kolovozu, oprašuje se kukcima, poznata je kao medonosna biljka. Uspijeva u uvjetima umjerene kontinentalne klime, traži visoko učešće vlage, u sušnim uvjetima ugiba. Vrlo je osjetljiva na mraz. Dolazi na osunčanim do poluzasjenjenim staništima. Podnosi široki spektar tala, od siromašnih do bogatih dušikom, osrednjega je učešća humusa i umjerene kiselosti. Razmnožava se sjemenkama, a vrlo dobro ju rasprostranjuje voda. U optimalnim uvjetima staništa vrlo je agresivna i kompetitvna s autohtonom vegetacijom koju potiskuje i tako smanjuje bi- 
oraznovrsnost. Uz obale tekućica povećava opasnost od erozije (Trinajstić 1974; Kranjčev 2007; Šoštarić 2011; Franjić i Škvorc 2014; Nikolić i dr. 2014).

$\mathrm{Na}$ Kalniku dolazi u nizinama i uz vodotoke. Vrlo naglo i snažno razvija se na čistim površinama nakon sječe kultura četinjača. Tu razvija guste sastojine koje onemogućavaju dolazak drugih vrsta, ali i otežava pošumljavanja, zbog čega ga se kemijski uklanja (glifosati) prije sadnje. Izuzetno vlažne i tople godine omogućavaju snažno širenje ali i plodonošenje, tako da se očekuje pojačana invazija.

\section{Juncus tenuis Willd. (Juncaceae) - nježni sit}

(= J. aristatus Link, J. chloroticus Schult., J. germanorum Steud., J. gesneri Sm., J. gracilis Sm. non Roth, J. lucidus Hochst., J. macer Gray, J. smithii Kunth)

njem. Zarte Binse

Nježni je sit podrijetlom iz Sjeverne i Južne Amerike. Pretpostavlja se daje u Europu unesena slučajno s krmnim biljem krajem 18. stoljeća. U svijetu je još zabilježena na području Azije, Afrike, Australije i Novoga Zelanda. Za područje Hrvatske prvi se puta navodi sredinom 1960-tih, a danas je rasprostranjena u kontinentalnom području. Preferira umjereno topla staništa, umjereno kisela tla osrednje količina humusa i dušika te izmjenične vlage. Pojavljuje se na tlima sitnih čestica gline, nepropusnih za vodu i siromašnima kisikom. Zauzima antropogena staništa, uz rubove putova, često i same putove, jer podnosi gaženje. Štetna je kao korovska i invazivna vrsta (Vuković 2011; Horvat 2011; Franjić i Škvorc 2014; Nikolić i dr. 2014).

$\mathrm{Na}$ Kalniku se javlja sporadično uz putove i na putovima, ali i na vlažnijim dijelovima golih sječina nastalih sječom kultura četinjača ili unutar prirodno pomlađenih površina. Ne čini za šumu značajnije štete, a uništava se kemijski (glifosati) zajedno s drugim korovima u pripremi staništa za pošumljavanje.

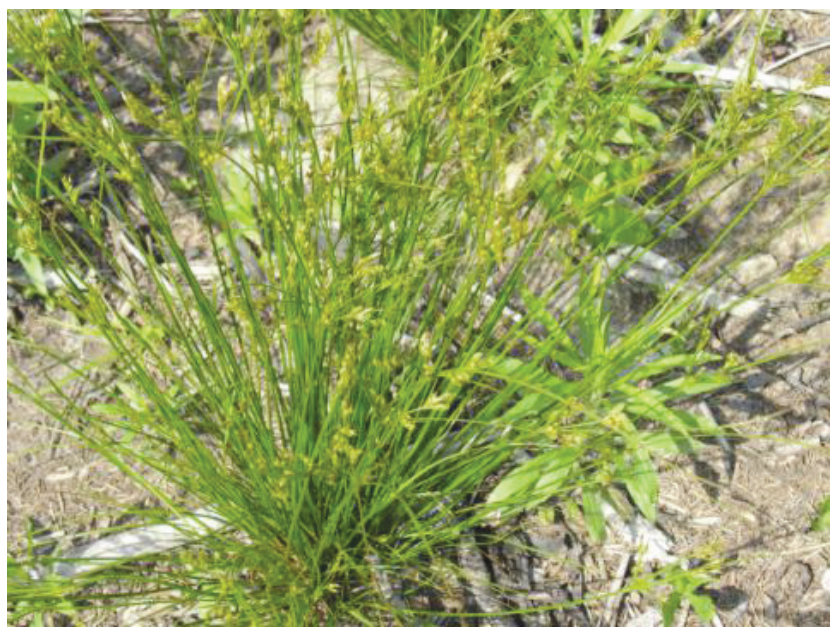

Slika 10. Nježni sit (Juncus tenuis Willd.).

\section{Phytolacca americana L. (Phytolaccaceae) - vinobojka}

(= Ph. decandra L.)

(= američki kermes, solima, kermes, grozdoboja, murićep, solina)

eng. American Pokeweed; njem. Amerikanische Kermesbeere; fra. Phytolaque américain

Zeljasta trajnica podrijetlom iz Sjeverne Amerike, namjerno unesena u Francusku kao dekorativna vrsta krajem 18. ili početkom 19. stoljeća. U svijetu dolazi još na staništima Srednje i Južne Amerike te Azije (dijelovi Kine). U Hrvatskoj se prvi puta navodi krajem 19. stoljeća i do sada se rasprostranila u sve dijelove zemlje. Osim nekih ljekovitih svojstava, u starijoj dobi su korijen i plodovi vrlo otrovni. Široke je ekološke amplitude. Preferira umjereno kisela te umjereno vlažna tla siromašna do osrednje bogata dušikom i humusom. Traži puno svjetla i izrazito je termofilna vrsta. Nastanjuje ruderalna, ali i druga poluprirodna staništa s dosta vlage. Dolazi uz putove, vodotoke, rubove šuma, kao i šumske čistine i sječine. Vrlo dobro se prilagođava suhim, škrtim i siromašnim staništima, npr. Đurđevački pijesci. U povoljnim uvjetima tvori guste sastojine kojima potiskuje autohtonu vegetaciju i usporava sukcesiju vegetacije. Sveukupno smanjuje biološku raznovrsnost (Kranjčev2007; Šoštarić 2011; Horvat 2011; Nikolić i dr. 2014).

$\mathrm{Na}$ Kalniku je uočena krajem prošloga stoljeća u progaljenim kulturama četinjača na jugoistočnim padinama (Kranjčev 2007). Danas se javlja na mnogim za svoj razvoj tipičnim staništima, a posebno se često i u velikome broju pojavljuje na čistim površinama nakon sječe posušenih kultura četinjača. Tu tvori guste i visoke sastojine koje onemogućavaju jesensko pošumljavanje, dok u mladim sastojinama zasjenjuju mlade biljke. Zbog iznadprosječno vlažne, ali i tople prošle godine, vinobojka je obilato plodonosila i

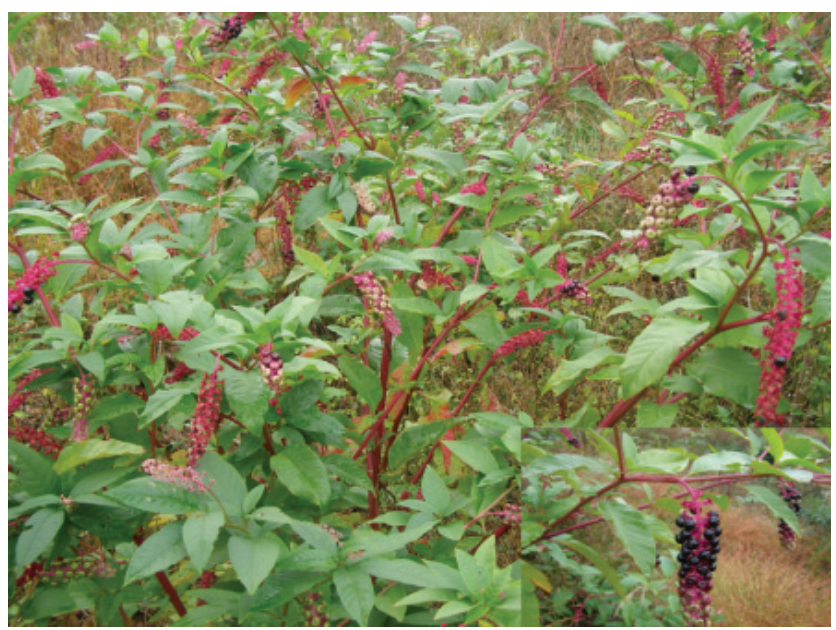

Slika 11. Vinobojka (Phytolacca americana L.). 
očekuje se jaka invazija. Uklanja se kemijski (glifosati) u pripremi staništa za pošumljavanje, odnosno sječom u mladim sastojinama.

Reynoutria japonica Houtt. (Polygonaceae) - japanski dvornik

(= Fallopia japonica/Houtt./ Ronse Decr., Pleuropterus cuspidatus /Siebold et Zucc./ H. Gross, Polygonum cuspidatum Siebold et Zucc., P. reynoutria Makino, P. sieboldii Reinw. ex Vries, P. zuccarinii Small, Tiniaria cuspidata /Houtt./ Hedb.)

eng. Japanese Knotweed; njem. Japanischer Flügelknöterisch, Japanischer Staudenknöterich

Zeljasta trajnica-geofit podrijetlom iz istočne Azije, namjerno je unijeta u Europu kao ukra-

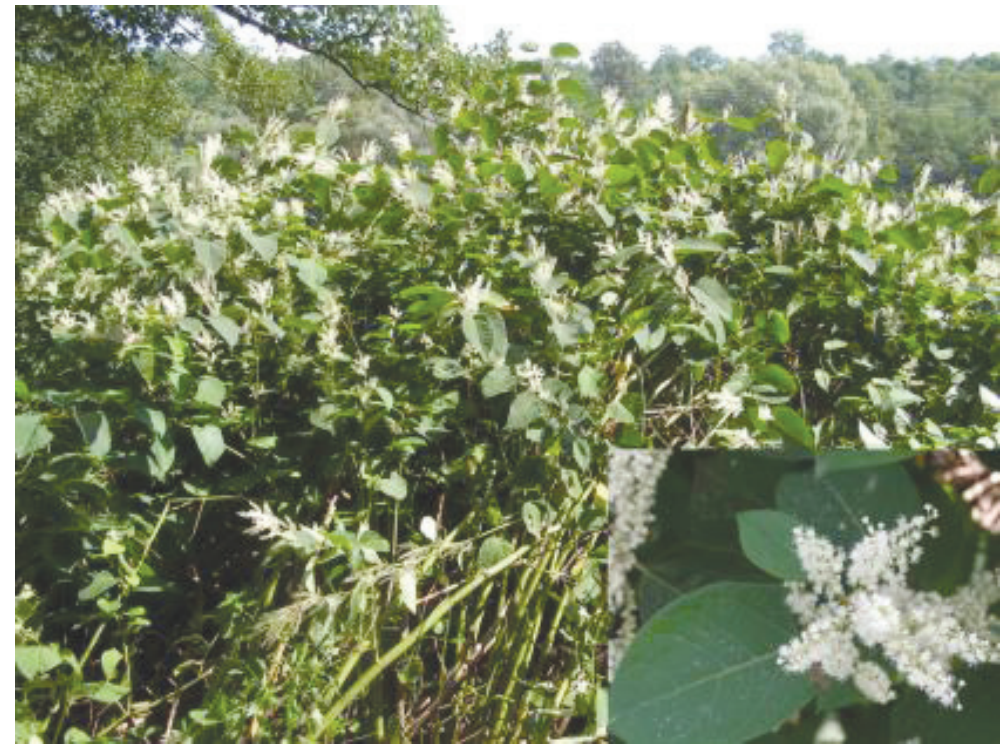

Slika 12. Japanski dvornik (Reynoutria japonica Houtt.). sna biljka u 19. stoljeću. Do sada je zabilježena još u Sjevernoj Americi, Australiji i na Novom Zelandu. Za Hrvatsku se navodi u prvoj polovici prošloga stoljeća. Danas dolazi najviše na području sjeverozapadne i istočne $\mathrm{Hr}$ vatske, te na području Gorskoga kotara, Like i Kvarnera. Cvjeta od srpnja do rujna, a oprašuju se kukcima, te je stoga korisna u pčelarstvu. Uspješno se razmnožava sjemenkama (rasprostranjuje se vodom i vjetrom), brzo se razmnožava i vegetativno, najčešće transportom zemlje kontamirane podancima pa je stoga vrlo agresivna i kompetitivna. Gustim sklopom onemogućava razvoj druge vegetacije zasjenjivanjem tla, a intenzivnim rastom obrašta podlogu i stvara uvjete za odrone i ispiranje tla. Termofilna je vrsta koja ne podnosi zasjenu, tolerantna je na vlagu, prilagođena je na manjak kisika u močvarnim uvjetima. Preferira staništa bogata dušikom, osrednje humozna tla različite kiselosti. Dolazi na svijetlim mjestima uz vodotoke, putove, rubove šuma, na travnjacima, sječinama i na drugim antropogenim staništima. Izrazito je invazivna vrsta, i osim na vegetaciju utječe i na promjenu kemijskoga sastava tla (Trinajstić 1990; Trinajstić i dr. 1991; Boršić 2011; Nikolić i dr. 2014).

$\mathrm{Na}$ Kalniku se javlja sporadično uz potoke, ceste i rubove šuma. U sjeveroistočnom dijelu tvori nekoliko većih sastojina. Za sada ne čini štete u šumama.

\section{Robinia pseudoacacia L. (Fabaceae) - bagrem}

(= obični bagrem, mirisavi bagrem, prženica, nerodik, bagrema, kapinika biela, krunčica, nerod, trn egjipski, trninaegiptonska, trnjina, bagrennerod, akacija, gacija, bagrena) eng. Black Locust; njem. Gewöhnliche Scheinakazie, Gewöhnliche Robinie; fra. Fauxacacia, Robinier; tal. Robinia

Listopadno drvo podrijetlom iz jugoistočnoga dijela SADa. Mnogo se kultivira tako da ga danas ima u velikom dijelu Sjeverne Amerike, južnom dijelu Južne Amerike, Europi,

umjerenom pojasu Azije, sjevernoj i južnoj Africi, Australiji i na Novom Zelandu. Sjemenke bagrema je iz SAD-a u Europu (Francusku) namjerno unio francuski dvorski vrtlar Jean Robin (po kojemu je dobio ime) 1601. godine. U Hrvatskoj je zabilježen početkom 20. stoljeća (iako je vjerojatno prisutan od ranije) i rasprostranio se je gotovo po čitavoj zemlji, s izuzetkom gorsko-planinskoga područja. Termofilna je biljka i teže uspijeva u zasjeni. Primarno uspijeva na suhim do umjereno vlažnim staništima, siromašnima dušikom koja može obogatiti vlastitom nitrifikacijom. Tolerira relativno širok raspon $\mathrm{pH}$-vrijednosti tla $(4,5-8,5)$. Vrlo je skromnih zahtjeva te se može prilagoditi na različita staništa, često kao pionirska vrsta. Osim što se kultivira, bagrem se spontano širi sjemenkama i vegetativno, tako da ga se može naći na različitim staništima (uz putove, uz željezničke pruge, na zapuštenim poljoprivrednim površinama, sječinama, šumskim rubovima, suhim travnjacima i kamenjarama i sl.). Brzo kolonizira kisela i zagađena tla. Zbog vrlo dobre prilagođenosti raznim tipovima staništa, bagrem je teško kontrolirati. Mehaničko uklanjanje i selektivno paljenje najčešće ne daju dobre rezultate, jer se biljka ubrzo dobro obnavlja korijenskim izdancima. Dobri se rezultati postižu raznim herbicidima uz sve njihove negativne sekundarne učinke. Iako u SAD-u bagrem ima svoje prirodne patogene, u Europi se pokazao kao visokootporan na gljive i druge patogene. Čitava je bilika otrovna, osim cvijeta (Call i Nilsen 2005; Franjić i Škvorc 2010; Kleinbauer i dr. 2010; Callaway i dr. 2011; Cseresnyes i Csontos 2012; Kimura i dr. 2013; Nikolić i dr. 2014; Nikolić 2015).

$\mathrm{Na}$ Kalniku se javlja u svim dijelovima, gdje često tvori čiste sastojine ili je u smjesi s drugim autohtonim vrstama - običnom bukvom, hrastom kitnjakom, običnim grabom (Horvat 2011,2012). Brzo se širi po zapuštenim i antropogenim staništima kao pionirska vrsta. Posebne probleme i velike 


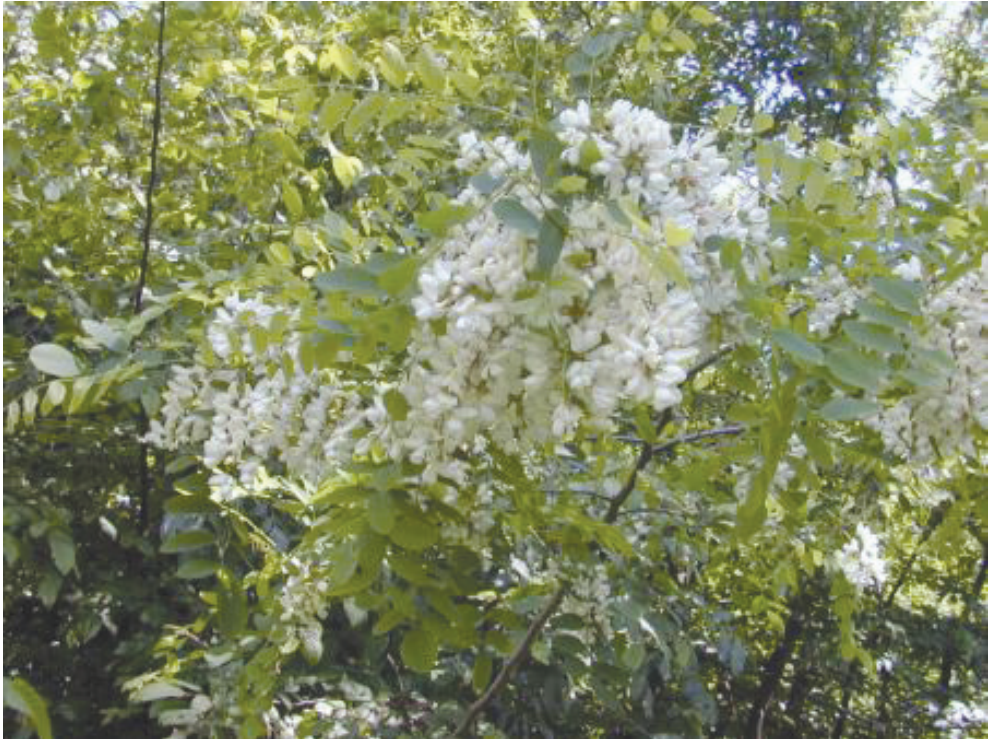

Slika 13. Bagrem (Robinia pseudoacacia L.).

štete čini na progaljenim površinama oplodnih sječina i površinama nakon čistih sječa i dovršnih sjekova u oplodnim sječama, kao i u mladim sastojinama. Vrlo ga je teško kontrolirati. Suzbija se uglavnom mehanički i kemijski (glifosati). Prevenciju je teško provoditi, budući da je vrlo rasprostranjen i omiljen u privatnim šumama gdje se koristi za stupove, kolje, ogrjev, pčelinju pašu i dr.

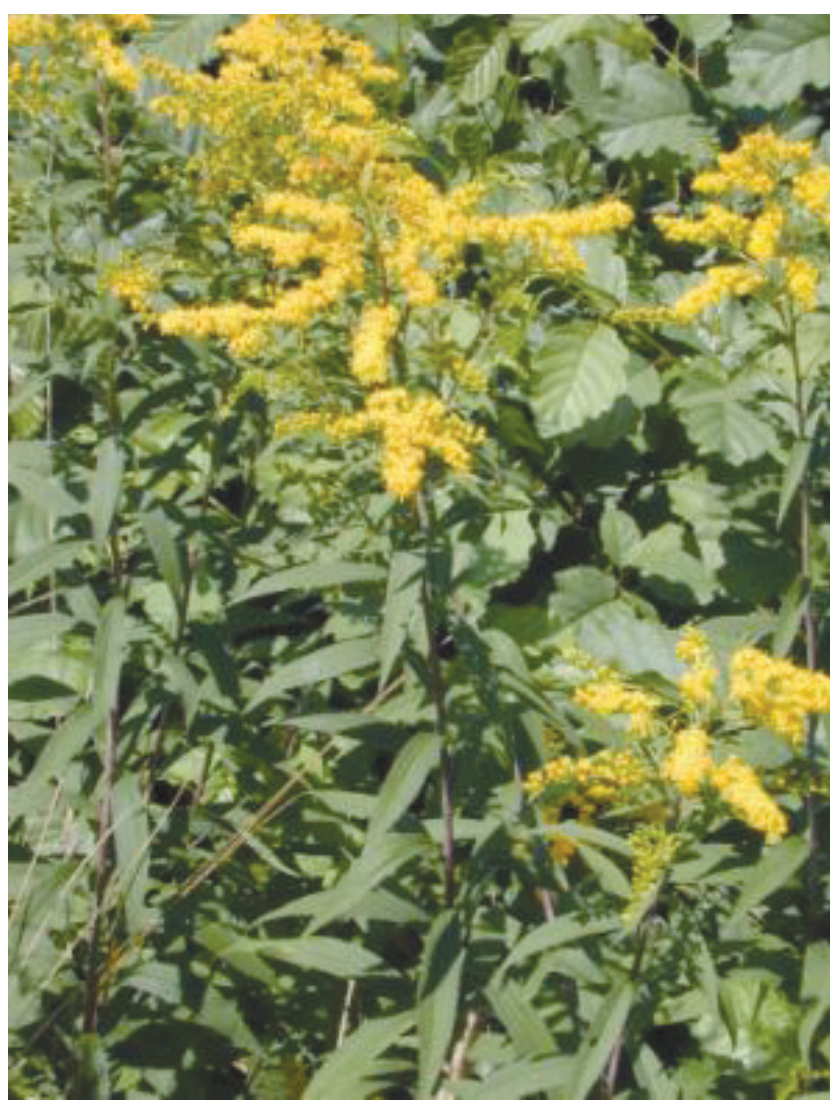

Slika 14. Velika zlatica (Solidago gigantea Aiton).

\section{Solidago gigantea Aiton (Asteraceae) -} velika zlatnica

(= S. gigantea ssp. gigantea, S. gigantea var. leiophylla Fernald, S. gigantea var. serotina /Kuntze/ Cronquist, S. serotina /O. Kuntze/ McNeill, S. serotina Aiton)

njem. Riesen-Goldrute, Späte Goldrute

Velika je zlatnica podrijetlom iz Sjeverne Amerike, a u Europu je unesena kao ukrasna bilika. Prvi puta je zabilježena 1758. godine u Engleskoj odakle se je proširila na srednju Europu. Danas dolazi i na području Azije. U Hrvatskoj se prvi puta spominje 1943. godine u području Podravine, a danas se javlja u svim područjima kontinentalne Hrvatske, s tendencijom zauzimanja lokaliteta sjevernoga primorja. Biljka je koja ne podnosi zasjenu, pa stoga dolazi na osunčanim staništima. Preferira umjereno kisela tla, promjenljive vlažnosti, bogata dušikom i humusom. Nastanjuje antropogena i poluprirodna staništa uz vodotoke, putove, nasipe, ali i prirodna staništa šumskih rubova, kao i otvorena suha staništa zapuštenoga poljoprivrednoga zemljišta. U šumi se javlja na plješinama prirodno obnovljenih sastojina, a posebno na površinama nakon čistih sječa. Svojim visokim stabljikama i gustim sklopom zasjenjuje ostalu autohtonu vegetaciju i onemogućava njezin razvoj, čime izravno utječe na sukcesiju vegetacije prema klimazonalnoj, ali i smanjuje bioraznovrsnost (Boršić 2011; Horvat2011; Franjić i Škvorc 20014; Nikolić i dr. 2014).

U šumama Kalnika javlja se također na svijetlim površinama mladih sastojina, a posebno na površinama nakon čistih sječa. Budući da ne podnosi zasjenu razvojem autohtone šumske vegetacije u potpunosti nestaje. Najčešće se uklanja kemijski (glifosati) s ostalim korovnim vrstama u pripremi staništa, odnosno mehanički u njezi mladih sastojina.

\section{RASPRAVA I ZAKLJUČAK DISCUSSION AND CONCLUSION}

Alohtona vegetacija je naša neizbježna stvarnost, ali i trajni izazov budućnosti u svijetu koji se sve više globalizira i komunicira na svim razinama i dostupnim načinima. Njezin utjecaj se definitivno ne smije marginalizirati. Njena važnost i utjecaj nije u potpunosti negativan, no moguće koristi ali i opasnosti treba kontrolirati kroz mjere prevencije i fizičke regulacije.

Na Kalniku i njegovoj šumskoj vegetaciji definitivno najvažnija vrsta je bagrem. Posebno to vrijedi za privatne šume u kojima je on zbog svojih korisnih svojstava postao vrlo zanimljiv, kao brzorastuća vrsta koja nema zahtjeva po pitanju podizanja i uzgoja i vrlo brzo daje rezultate kroz drvne sortimente, koji se uglavnom odnose na sitno teh- 
ničko drvo i ogrjev. Površine privatnih parcela su vrlo male i rascjepkane, a prisutna je velika potreba za drvnom masom, pa se na njima gospodari kratkim ophodnjama, ekstenzivno, uzgojem iz panja i korijenja. Ostale navedene drvenaste vrste za sada ne predstavljaju ozbiljniju opasnost u gospodarskom, ali ni u biološkom smislu. Utjecaj zeljastih vrsta je raznolik, a šumarskoj praksi najviše problema čine gusti sklopovi u mladim sastojinama ili onima u fazi obnove, gdje svojom invazivnošću konkuriraju autohtonim vrstama. U biološkom smislu invazivne vrste su trajna opasnost zavičajnoj vegetaciji i bioraznovrsnosti, ali i zdravlju ljudi. Svakako treba spomenuti i vrlo važnu i razvijenu djelatnost na Kalniku, a to je pčelarstvo za čije su potrebe navedene vrste jako zanimljive i važne, i to kao vrste bogate paše. Pčelarstvo ovoga kraja opstoji na bagremovoj paši pa je to još jedan od vrlo bitnih razloga njegova uzgoja. Ostale vrste su također vrijedna paša, posebice $u$ kasnijem razdoblju jeseni kada nema ostale paše, a neke vrsta tada cvjetaju i predstavljaju vrijedni izvor peluda (japanski dvornik, divlji krastavac, cigansko perje i velika zlatnica).

Općenito gledajući, najveća odgovornost za moguće posljedice utjecaja invazivne flore na šume Kalnika leži na šumarima koji svojim znanjem moraju prepoznati i pratiti stanje nadolaska invazivnih vrsta, posebice u državnim šumama u kojima gospodare i izravno utječu na njihov sastav i stanje.

\section{LITERATURA}

\section{REFERENCES}

- Boršić, I., 2011: Ailanthus altissima (Mill.) Swingle. U: Nikolić, T. (ur.): Flora Croatica baza podataka - Alohtone biljke. On-line http.//hirc.botanic.hr/fcd/InvazivneVrste. Sveučilište u Zagrebu - PMF-Botanički zavod, 1-12.

- Boršić, I., 2011: Ambrosia artemisiifolia L. U: Nikolić, T. (ur.): Flora Croatica baza podataka - Alohtone biljke. On-line http.// hirc.botanic.hr/fcd/InvazivneVrste. Sveučilište u Zagrebu - PMFBotanički zavod, 1-21.

- Boršić, I., 2011: Amorpha fruticosa L. U: Nikolić, T. (ur.): Flora Croatica baza podataka - Alohtone biljke. On-line http.//hirc. botanic.hr/fcd/InvazivneVrste. Sveučilište u Zagrebu - PMFBotanički zavod, 1-18.

- Boršić, I., 2011: Reynoutria japonica Hout. U: Nikolić, T. (ur.): Flora Croatica baza podataka - Alohtone bilike. On-line http.// hirc.botanic.hr/fcd/InvazivneVrste. Sveučilište u Zagrebu - PMFBotanički zavod, 1-9.

- Boršić, I., 2011: Solidago canadensis L. U: Nikolić, T. (ur.): Flora Croatica baza podataka - Alohtone biljke. On-line http.//hirc. botanic.hr/fcd/InvazivneVrste. Sveučilište u Zagrebu - PMFBotanički zavod, 1-9.

- Call, L. J., E. T. Nilsen, 2005: Analysis of interactions between the invasive tree-of-heaven (Ailanthus altissima) and the native black locust (Robinia pseudoacacia). Plant Ecology 176(2): 275-285.

- Callaway, R. M., E. J. Bedmar, K. O. Reinhart, C. G. Silvan, J. Klironomos, 2011: Effects of soil biota from different ranges on Robinia invasion: acquiring mutualists and escaping pathogens. Ecology 92(5): 1027-1035.
- Cseresnyés, I., P. Csontos, 2012: Soil seed bank of the invasive Robinia pseudoacacia in planted Pinus nigra stands. Acta Bot. Croat. 71(2): 249-260.

- Domac, R., 1994: Flora Hrvatske. Priručnik za određivanje bilja. Školska knjiga, Zagreb.

- Franjić, J., Ž. Škvorc, 2010: Šumsko drveće i grmlje Hrvatske. Sveučilište u Zagrebu - Šumarski fakultet, 432 str. Zagreb.

- Franjić, J., Ž. Škvorc, 2014: Šumsko zeljasto bilje Hrvatske. Sveučilište u Zagrebu - Šumarski fakultet, 626 str. Zagreb.

- Horvat, G., 2011: Sukcesija vegetacije nakon sječe kultura četinjača na Kalniku, Disertacija - Sveučilište u Zagrebu-Šumarski fakultet, Zagreb.

- Horvat, G., 2012: Šume Kalnika. Tonimir, Znanstvena biblioteka, Knjiga broj 38, 11-29 str. Varaždinske Toplice

- Javorka, S., V. Csapody, 1991: Iconographia florae partis Austroorientalis Europae centralis. Akademiai Kiado, Budapest.

- Kimura, M. K., C. Lian, T. Hogetsu, 2013: Isolation and characterization of chloroplast microsatellite markers in the invasive tree species Robinia pseudoacacia L. Silvae Genetica 62(4-5): 207-209.

- Kleinbauer, I., S. Dullinger, J. Peterseil, F. Essl, 2010: Climate change might drive the invasive tree Robinia pseudacacia into nature reserves and endangered habitats. Biological Conservation 143: 382-390.

- Kranjčev, R., 2007: Neofiti Podravine, Šum. list 131(3-4): 165-167.

- Krpan, A., Ž. Tomašić, P. Bašić Palković, 2011: Biopotencijal amorfe (Amorpha fruticosa L.) - druga godina istraživanja. Šum. list - Posebni broj 135(13): 103-113.

- Martinčič, A., T. Wraber, N. Jogan, V. Ravnik, A. Podobnik, B. Turk, B. Vreš, 1999: Mala Flora Slovenije. Ključ za določanje praprotnic in semenk. Ljubljana, Tehniška Založba Slovenije. 845 str.

- Mitić, B., I. Boršić, I. Dujmović, S. Bogdanović, M. Milović, P. Cigić, I. Rešetnik, T. Nikolić, 2008: Alien flora of Croatia: proposals for standards in terminology, criteria and related database. Nat. Croat. 17(2): 73-90.

- Nikolić, T. (ur.), 2015: Flora Croatica baza podataka (http://hirc. botanic.hr/fcd). Sveučilište u Zagrebu - Prirodoslovnomatematički fakultet (datum pristupa:14.05.2015).

- Nikolić, T., B. Mitić, I. Boršić, 2014: Invazivne biljke, Alfa d.d. 296 str. Zagreb.

- Pandža M., J. Franjić, I. Trinajstić, Ž. Škvorc, Z. Stančić, 2001: The most recent state of affairs in the distribution of some neophytes in Croatia. Nat. Croat. 10(4): 259-275.

- Perković, I., N. Pernar, B. Vrbek, D. Bakšić, I. Pilaš, M. Presečan, 2007: Utjecaj kulture obične smreke na tlo. Radovi 42(2): 95-107

- Peternel, R., J. Čulig, L. Srnec, B. Mitić, I. Vukušić, I. Hrga, 2005: Variation in Ragveed (Ambrosia artemisiifolia L.) pollen concetration in central Croatia, 2002-2003. Ann. Agric. Environ. Med.12: 11-16.

- Rothmaler, W. 2000: Exkursionsflora von Deutschland. Bd. 3. Spektrum, Berlin.

- Šoštarić, R., 2011: Robinia pseudacacia L. U: Nikolić, T. (ur.): Flora Croatica baza podataka - Alohtone biljke. On-line http.//hirc. botanic.hr/fcd/InvazivneVrste. Sveučilište u Zagrebu - PMFBotanički zavod, 1-17.

- Šoštarić, R., 2011: Acer negundo L. U: Nikolić, T. (ur.): Flora Croatica baza podataka - Alohtone bilike. On-line http.//hirc.botanic. $\mathrm{hr} / \mathrm{fcd} /$ InvazivneVrste. Sveučilište u Zagrebu - PMF-Botanički zavod, 1-8. 
- Šoštarić, R., 2011: Asclepias syriaca L. U: Nikolić, T. (ur.): Flora Croatica baza podataka - Alohtone bilike. On-line http.//hirc. botanic.hr/fcd/InvazivneVrste. Sveučilište u Zagrebu - PMFBotanički zavod, 1-8.

- Šoštarić, R., 2011: Impatiens glandulifera Royle U: Nikolić, T. (ur.): Flora Croatica baza podataka - Alohtone biljke. On-line http.// hirc.botanic.hr/fcd/InvazivneVrste. Sveučilište u Zagrebu - PMFBotanički zavod, 1-7.

- Šoštarić, R., 2011: Phytolacca americana L. U: Nikolić, T. (ur.): Flora Croatica baza podataka - Alohtone biljke. On-line http.// hirc.botanic.hr/fcd/InvazivneVrste. Sveučilište u Zagrebu - PMFBotanički zavod, 1-6

- Trinajstić, I., 1974: Ein neur Fundort von Impatiens glandulifera Royle in Kroatien. Fragm. Herbol. Jugosl. 40: 1-6.

- Trinajstić, I., 1990: Prilog poznavanju rasprostranjenosti vrste Reynoutria japonica Houtt. (Polygonaceae) u Jugoslaviji. Fragm. Herbol. 2(19): 139-143 .

- Trinajstić, I., J. Franjić, D. Kajba, 1991: Prilog poznavanju rasprostranjenosti vrste Echinocystis lobata (Michx.) Torr. et Gray u Hrvatskoj Fragm. Herb. 20(1-2): 69-74.

- Trinajstić, I., J. Franjić, D. Kajba, 1994: Prilog poznavanju rasprostranjenosti vrste Reynoutria japonica Houtt. (Polygonaceae) u Hrvatskoj. Acta Bot. Croat. 53: 145-149.
- Trinajstić, I., J. Franjić, D. Kajba, J. Samardžić, 1991: Današnje stanje rasprostranjenosti vrste Reynoutria japonica Houtt. (Polygonaceae) u Hrvatskoj. Fragm. Herbol. 20(1-2): 63-67.

- Trinajstić, I., J. Franjić, D. Kajba, 1994: Prilog poznavanju vrste Reynoutria japonica Houtt. (Polygonaceae) u Hrvatskoj. Acta Bot. Croat. 53: 145-149.

- Vuković, N., 2011: Conyza canadensis (L). Cronquist. U: Nikolić, T. (ur.): Flora Croatica baza podataka - Alohtone biljke. On-line http.//hirc.botanic.hr/fcd/InvazivneVrste. Sveučilište u Zagrebu - PMF-Botanički zavod, 1-25.

- Vuković, N., 2011: Echinocystis lobata (Michx.) Torr. et Gray U: Nikolić, T. (ur.): Flora Croatica baza podataka - Alohtone biljke. On-line http.//hirc.botanic.hr/fcd/Invazivne Vrste. Sveučilište u Zagrebu - PMF-Botanički zavod, 1-8.

- Vuković, N., 2011: Erigeron annuus (L.) Pers. U: Nikolić, T. (ur.): Flora Croatica baza podataka - Alohtone biljke. On-line http.// hirc.botanic.hr/fcd/InvazivneVrste. Sveučilište u Zagrebu - PMFBotanički zavod, 1-27.

- Vuković, N., 2011: Juncus tenuis Willd. U: Nikolić, T. (ur.): Flora Croatica baza podataka - Alohtone bilike. On-line http.//hirc. botanic.hr/fcd/InvazivneVrste. Sveučilište u Zagrebu - PMFBotanički zavod, 1-6.

\section{Summary}

This paper presents an invasive plant species that occur in the forests of Kalnik. It also presents the state of the distribution and their impact on forests of Kalnik. A total of 14 invasive species in the forests of Kalnik and these are - Acer negundo L., Ailanthus altissima (Mill.) Swingle, Ambrosia artemisiifolia L., Amorpha fruticosa L., Asclepias syriaca L., Conyza canadensis (L.) Cronquist, Echinocystis lobata (Michx.) Torr. et Gray, Erigeron annuus (L.) Pers., Impatiens glandulifera Royle, Juncus tenuis Willd.), Phytolacca americana L., Reynoutria japonica Houtt., Robinia pseudoacacia L., Solidago gigantea Aiton. Alochtonous vegetation is not only inevitable, but it also appears to be a constant future challenge in the globalizing world which communicates on all levels with every means possible. Its influence should not by any means be marginalized. Its importance and influence is not completely negative and there are possible benefits and dangers which should be controlled by the preventive measures and physical regulation. The most important species in Kalnik forest vegetation is definitely acacia. It is especially important for private forest lands where acacia tree has become very popular because of its characteristics as a fast growing tree species without any special requirements with relation to growth and it gives fast results concerning timber and firewood. Private lots are usually very small and fragmented. There is a growing need for timber, therefore the trees are grown extensively, from stumps and roots. Other woody species still do not pose a serious threat in economical or biological sense. The impact of herbaceous plants differs in various areas. The most problematic issues for the forestersare thick layers of unwanted specieswhich grow in young forest stands or in forests in the phase of restorationwhere these unwanted speciesinvasively compete with autochthonous species. In biological sense, invasive species pose a constant threat not only to domestic vegetation and biodiversity, but also to human health. We should also mention apiculture, a very important and well developed activity on Kalnik. Above mentioned species are very important and interesting for apiculture as a type of rich bee pasturage. Apiculture in this area depends on acacia pasturage and it is one of very important reasons for growing acacia tree. Other tree species are also valuable for bee pasturage, especially late in autumn when there is no other bee pasturage available and they are mostly species which blossom in autumn and represent a valuable source of pollen (Japanese Knotweed, Prickly cucumber and European goldenrod). Generally speaking, the biggest responsibility for possible consequences of invasive plant species to the vegetation of Kalnik lies on foresters who have to recognize and monitor the appearance of invasive species, especially in state forest lands where they grow and directly influence their composition and state. 